\title{
Effects of improved pigeonpea fallows on biological and physical soil properties and their relationship with maize yield
}

\author{
Misheck Musokwa (i) Paramu L. Mafongoya
}

Received: 17 March 2020/ Accepted: 2 January 2021 / Published online: 26 January 2021

(C) The Author(s) 2021

\begin{abstract}
Declining soil properties have triggered lower maize yields among smallholder famers in South Africa. Legume trees such as pigeonpea can be used as improved fallows to replenish degraded soils. The objectives of the study were to: (1) examine the effects of improved pigeonpea fallows on enhancing biological, physical soil properties and maize yield responses and (2), analyze the relationship of maize grain yield to biological and physical soil properties after improved pigeonpea fallows at Wartburg, South Africa. Pigeonpea fallows were established in 2015/16 season and terminated in 2017 and subsequently maize was planted. A randomized complete block design replicated three times was used with five treatments: continuous sole maize without fertilizer (T1), natural fallow then maize (T2), pigeonpea + grass-pigeonpea then maize (T3), maize + pigeonpea-pigeonpea then maize (T4), two-year pigeonpea fallow then maize (T5). Improved pigeonpea fallows increased maize yields through improvement in soil macrofauna species abundance, richness and diversity, aggregate
\end{abstract}

M. Musokwa ( $\bowtie) \cdot$ P. L. Mafongoya

University of KwaZulu-Natal, Agricultural, Earth and

Environmental Sciences, Bag X01,

Pietermaritzburg 3209, South Africa

e-mail: mmusokwa@gmail.com

M. Musokwa

Institute of Natural Resources,

P.O Box 100 396, Scottsville, Pietermaritzburg 3209,

South Africa stability, infiltration rate. Pigeonpea fallows increased maize yield by 3.2 times than continuous maize without fertilizer. The maize grain yield (3787 $\mathrm{kg} \mathrm{ha}^{-1}$ ), was the highest on two-year pigeonpea fallows while continuous maize without fertilizer had the least $\left(993 \mathrm{~kg} \mathrm{ha}^{-1}\right)$. There was a significant positive correlation between soil macrofauna indices and physical soil properties to maize yields. Smallholders who have limited access to fertilizers can sustainably use improved fallows to restore degraded soils to achieve higher maize yields in South Africa.

Keywords Aggregate stability $\cdot$ Smallholder farmers $\cdot$ Soil degradation $\cdot$ Soil macrofauna $\cdot$ Soil replenishment

\section{Introduction}

Soil degradation in high density areas of the African continent is exacerbated by unsustainable management agricultural practices that have led to biological, chemical and physical soil degradation (Drechsel et al. 2001; Tittonell and Giller 2013; Zingore et al. 2015). According to Barbier and Hochard (2016) approximately $28 \%$ of rural Africa's farmers cultivate land that is degrading over time. In addition sub-Saharan Africa (SSA) is experiencing the fastest increase in the percentage of rural households tilling on degraded 
land as compared to other regions in the world (Tittonell and Giller 2013). A holistic land management strategy is needed, that focuses on restoring degraded land which is essential to feed and to support the livelihoods of ever increasing population in SSA (Kihara et al. 2016; Tittonell 2016). The traditional method of restoring degraded land in the past was to regularly fallow the land for a period of single to many seasons to ameliorate its fertility in addition to the use of chemical fertilizers, green manure or use of both organic and inorganic inputs (Sanchez 1999). The rise in population has exerted pressure on the land which has eroded the propensity of traditional fallowing practices to sustain and reinstate soil fertility in SSA. (Josephson et al. 2014). The advent of short fallow periods using fast nitrogen fixing legume trees on degraded agricultural fields have shown to replenish degraded soils and increase crop productivity under smallholder farming systems (Sanchez 1999; Mafongoya et al. 2006; Munthali et al. 2014). Sequential agroforestry practices involve the use fast growing legume trees as fallows. They are an alternative or complement to the use of chemical fertilizers, mainly in SSA where they are not regularly accessible and when available their prices are prohibitive beyond reach by many smallholder farmers (Bationo and Waswa 2011; Sileshi et al. 2014). Sequential tree fallows is a practice where fast nitrogen-fixing legume trees are planted for 2-3 years, additionally it is known as "improved fallows" (Mafongoya et al. 2006). Improved fallows replenish degraded agricultural fields quicker than natural fallows.

Previous research on improved fallows in SSA have focused much on maize yield, chemical and physical soil properties (Phiri et al. 2003; Abunyewa and Karbo 2005; Sileshi et al. 2008a; Mafongoya and Jiri 2016; Mamuye et al. 2020). However, other studies have also focused on biological soil properties and maize yield (Sileshi and Mafongoya 2006,2006; Sileshi et al., 2008b; Barrios et al. 2012; Manyanga et al. 2014; Marsden et al. 2019). Nevertheless most of these studies did not examine how maize grain yield increase is related to biological and physical soil properties under pigeonpea improved fallows. Moreover, to our knowledge no studies have been conducted on the use of improved fallows to improve maize yields in South Africa (RSA). Although pigeonpea improved fallows have been shown to augment overall maize grain yield through improved soil properties (Sileshi et al. 2008a, b, 2014; Félix et al. 2018), there is paucity of data on whether maize grown after pigeonpea improved fallows in RSA, will increase yield as compared to continuous sole maize cropping with no external inputs (Everson et al. 2011).

Maize (Zea mays L.) is the main cereal food crop grown globally due to its adaptability to wider range of environments (Kogbe and Adediran 2003). It is mostly used as human food, livestock fodder and as a source of raw materials for various processing industries (Tian et al. 2009; Gwirtz and Garcia-Casal, 2014). According to Rosegrant et al. 2009, the demand for maize is expected to double by 2050 in the developing world. Most smallholder farmers in RSA grow maize as a staple food crop (Mashingaidze 2006). Maize yields have remained very low which ranges from 500 to $2000 \mathrm{~kg} \mathrm{ha}^{-1}$ which is too low to achieve household food security (Sanchez 2002; Musokwa et al. 2019) because of prohibitive prices that have hampered fertilizer usage by smallholder farmers and the supply of livestock manure is insufficient to augment the nutrient needs of maize (Everson et al. 2011). The declining soil fertility which is enhanced by continuous cultivation without external inputs (chemical fertilizers and organic inputs) applied have exacerbated the reduction in maize yields (Sanchez 2002; Swift and Shepherd 2007; Everson et al. 2011; Sileshi et al. 2011). The use of pigeonpea fallows on degraded soils has been shown to replenish degraded soils in addition to increase maize yields (Kwena et al. 2017; Mamuye et al. 2020). Pigeonpea (Cajanus cajan (L.) Millsp.) is legume crop which is below the potential use in RSA (Hluyako et al. 2017). The crop can provide food, fodder, fuelwood and as a source of fertilizer through biological nitrogen fixation and decomposition of leaf litter and dead roots (AduGyamfi et al. 2007; Musokwa et al. 2019). Pigeonpea can be used for legume base diversification to meet the rising demand for nutritional foods, since it contains proteins, vitamins as well as essential minerals (Hluyako et al. 2017).

Nevertheless, there is a need to examine the relationship of maize yields to biological and physical soil properties after pigeonpea fallows in RSA, since there are promising results from many studies in SSA that reveal improved pigeonpea fallows improves maize yield (Sileshi et al. 2008a, 2014; Félix et al. 2018). Pearson's correlation can be used to analyse causal relationships among soil properties or betwixt 
selected indicators and maize grain yield (Montanari et al. 2010; Silva et al.2017). The hypothesis was that pigeonpea fallows improved both biological and physical soil properties which will be related to maize grain yield. Our objectives were to (i) examine the effects of pigeonpea improved fallows on enhancing biological, physical soil properties and maize yield responses and (ii) analyze the relationship of maize grain yield to biological and physical soil properties after improved fallows using Pearson's linear correlation.

\section{Methodology}

Site description

The field trial was conducted from November 2015 to April 2018 cropping seasons in Wartburg, KwaZuluNatal, South Africa at Fountainhill Estate (latitude $29^{\circ} 27^{\prime} 2^{\prime \prime} \mathrm{S}$; longitude $30^{\circ} 32^{\prime} 42^{\prime \prime} \mathrm{E}$ and altitude $853 \mathrm{~m}$ ). Wartburg has a maximum temperature of $37.4{ }^{\circ} \mathrm{C}$ which can be experienced in November and minimum of $3.3{ }^{\circ} \mathrm{C}$ normally recorded in July. The mean annual rainfall is $880 \mathrm{~mm}$ which usually falls mostly in November until April. The study site received a total rainfall of about $2111.4 \mathrm{~mm}$ during study period from
November 2015 to April 2018 (Fig. 1). The soils are classified as ferralsols by the Food and Agriculture Organization of the United Nations (FAO) classification system with sandy, loam texture, (Faye 2010). The soils for experimental site have strongly acidic ( $\mathrm{pH} 4.4$ ), total soil organic carbon (OC) of $0.65 \%$, and have low $\mathrm{N}(0.06 \%)$ and available $\mathrm{P}$ content (20.4 mg kg ${ }^{-1}$ ). Soil analyses also indicated moderate $\mathrm{K}$ content $\left(114.2 \mathrm{mg} \mathrm{kg}^{-1}\right)$ in the soils. The initial soil characteristics after soil characterization are shown in the Table 1.

Table 1 Soil characteristics at Fountainhill Estate Farm, Wartburg, Source Musokwa et al. (2019)

\begin{tabular}{ll}
\hline Parameter & Value \\
\hline Total Nitrogen $(\%)$ & 0.06 \\
Total Phosphorus $\left(\mathrm{mg} \mathrm{kg}^{-1}\right)$ & 20.4 \\
Total Potassium $\left(\mathrm{mg} \mathrm{kg}^{-1}\right)$ & 114.2 \\
Total Cations $\left(\mathrm{cmol} \mathrm{kg}^{-1}\right)$ & 3.59 \\
Organic Carbon $(\%)$ & 0.65 \\
pH $(\mathrm{KCI})$ & 4.37 \\
Clay $(\%)$ & 16 \\
\hline
\end{tabular}

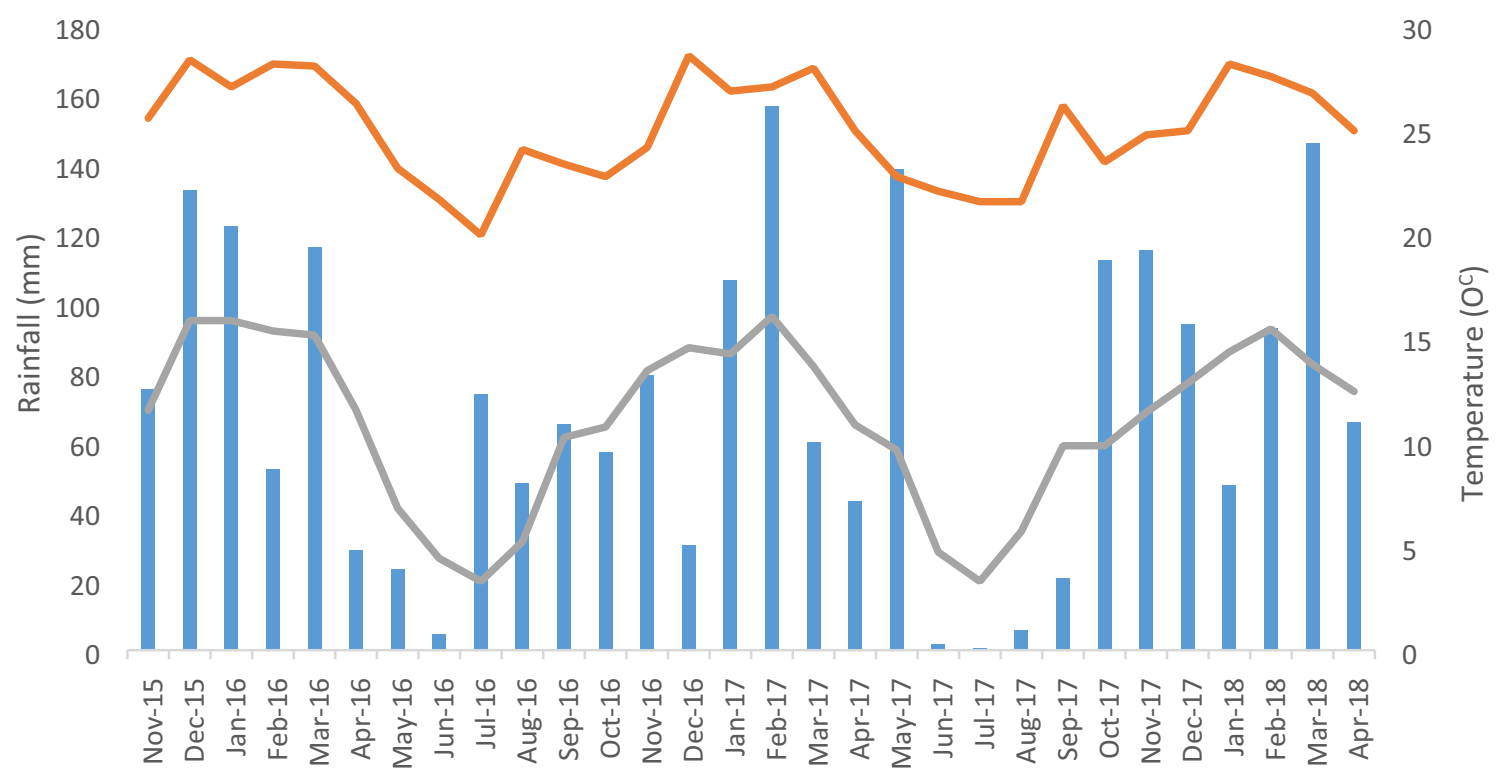

Fig. 1 Mean monthly rainfall for during fallow phase and cropping season November 2015-April 2018 
Trial Design and management

The experiment had five treatments described in Table 2. The treatments were laid out in a randomized complete block design (RCBD), replicated three times. The plots measured $8 \mathrm{~m}$ by $6 \mathrm{~m}$ with a net plot area $5 \mathrm{~m} \times 7 \mathrm{~m}$. Pigeonpea fallows were planted as pure stands at a spacing of $1 \mathrm{~m}$ by $1 \mathrm{~m}$. The mixed crop of pigeonpea and maize had $1 \mathrm{~m} \times 0.4 \mathrm{~m}$ spacing whereas Panicum maximum grass was planted in between pigeonpea rows at a rate of $7.5 \mathrm{~kg} \mathrm{ha}^{-1}$ with inter-row spacing of $0.25 \mathrm{~m}$ planted in rows in November 2015. The two-year fallow duration was chosen for this study after recommendation by Mafongoya and Dzowela (1999), based on fallow fertility replenishment. Four by $0.5 \mathrm{~m} \times 0.5 \mathrm{~m}$ quadrats were randomly taken from each plot to record the quantity of dry leaf litter fall accumulation on the surface of the soil on a monthly basis. The pigeonpea fallow was terminated during the first week of November 2017 after two-years, the axe was used to cut down pigeonpea trees while the stumps were left to decompose and the natural fallow was cleared using a hand-hoe. Maize Border King was sown at $0.90 \mathrm{~m}$ between rows and $0.30 \mathrm{~m}$ within rows on 22 November 2017 and harvested on 14 May 2018. Two seeds were planted per hole and then thinned after twoweeks of emergence to one plant to give a maize population of 37,000 plants $^{-1} \mathrm{a}^{-1}$ The plots were kept weed free by hand weeding two times across the whole season, while T2 (described in Table 2), representing natural fallow under weed, was not weeded during the two-year fallow period no fertilizer was applied on this study. At maturity, the mass of grain and stover were recorded in the entire net plot. At the end, maize grain yields were sun dried until it reached $12 \%$ moisture content. This data was used to calculate dry mass on plot basis and extrapolated to a hectare basis.

\section{Soil fauna data collection}

To analyze soil macrofauna the procedures recommended by Tropical Soil Biology and Fertility (Anderson and Ingram 1993) was executed across each treatment, three monoliths comprising steel blocks measuring $25 \mathrm{~cm} \times 25 \mathrm{~cm} \times 25 \mathrm{~cm}$ were used for sampling soil macrofauna in November 2017. The macrofauna in each monolith was detached by hand and kept in $70 \%$ ethanol and segregated according to their structure (Dangerfield 1997). Soil macrofauna was described as an invertebrate group found inside soil samples that constitutes greater than $90 \%$ of its specimens visible to the naked eye (Lavelle et al. 2003). The collected soil macrofauna was identified using a microscope at the level of recognizable taxonomic units that is family and order level.

Determination of chemical and physical soil properties

Soil samples were collected from the $0-20 \mathrm{~cm}$ soil depths using metal cores to analyse for chemical and physical soil properties. Soil $\mathrm{pH}$ was determined by a $\mathrm{pH}$ meter and organic carbon by the Walkley and Black method as described by Nelson and Sommers (1982).Total N was analysed by the Kjeldhal method as explained by Bremner and Mulvaney (1982). Available $\mathrm{P}$ was measured using Bray 2 method as explained by Olsen and Sommers (1982).

Cation exchange capacity (CEC) and exchangeable cations (K) were analysed by the ammonium acetate method at pH 7 (Chapman and Pratt 1965). Soil bulk

Table 2 Description of the treatments established at Fountainhill Estate, Wartburg

\begin{tabular}{llll}
\hline Treatments & Seasonal period & & \\
\cline { 2 - 4 } & $2015-2016$ & $2016-2017$ & Maize \\
\hline T1 & Maize with no fertilizer & Maize with no fertilizer & Maize \\
*T2 & Natural Fallow & Natural Fallow & Maize \\
T3 & Pigeonpea + Panicum maximum & Pigeonpea & Maize \\
T4 & Pigeonpea + maize & Pigeonpea & Maize \\
T5 & Pigeonpea & Pigeonpea & \\
\hline
\end{tabular}

${ }^{*}$ T2 The natural fallow had dominant grasses which include Aragrostis curvula, Bidens pilosa and Cynodon dactylon 
density was analysed using method described by Lal and Kimble (2010) hence it was computed as the mass of oven dry soil divided by the volume of the soil as shown in Eq. 1.

$q b \mathrm{Mgm}^{-1}=\frac{M s}{V t}$

where Ms = mass of oven dry soil and Vt $=$ total volume of soil.

To analyse soil aggregate stability, mean weight diameter, a 25-g part of soil aggregates, with diameters measuring 6.30-4.00 mm, was taken to a set of sieves in declining order of mesh sizes: 4.00, 2.00, 1.00, 0.50, 0.25 , and $0.125 \mathrm{~mm}$. The sieve set was immersedwith the aggregates without pre-wetting - in water, in an apparatus for vertical oscillation (Yoder 1936) during $15 \mathrm{~min}$, calibrated to 31 cycles per min. The mean weight diameter (MWD, $\mathrm{mm}$ ) was calculated as (Choudhury et al. 2014)

$\sum_{k=1}^{n} X k \times M k$

where $k$ is aggregate size $(k=1,2,3$ indicate macroaggregate, micro-aggregate and silt + clay-sized fraction); $X_{k}(\mathrm{~mm})$ is the mean diameter of the sized aggregate; and $M_{k}(\%)$ is the mass propsortion of the sized aggregate. Soil infiltration count was examined from double rings in net plot. A persistent infiltration rate was presumed to have been obtained when five similar successive readings were reached (Ren et al. 2012).

Data analysis

All data were tested for normality of distributions and homogeneity of variances before the analysis. The different soil taxa encountered and abundance of each were used to calculate species richness $(S=$ total number of taxonomic groups) as well as the Shannon index of diversity (Shannon and Wiener 1963).

$H^{\prime}=-\sum_{i=1}^{s} p_{i} \ln p_{i}$

where $p i$ is the proportion of the species belonging to the $i$ th order in each sample.

Soil macrofauna species abundance, diversity and richness indices, maize grain, stover yield and physical soil properties data were subjected to analysis of variance (ANOVA) with GenStat Release 18.2. Mean comparisons for the individual treatments were done using Tukey's Honest Significant Difference Test (LSD, $p \leq 0.05$ ). Pearson correlation coefficients (r) for the maize grain yield, leaf litter and soil physical and macrofauna were computed.

\section{Results}

Effect of pigeonpea fallows on soil macrofauna

Meloidae (beetles), Pheidole (ants), Technomyrmex (ants), Camponotus (ants) and Oligochaeta (earthworms) were the most five dominant orders of macrofauna observed in almost all treatments, with two-year pigeonpea fallow plots harboring more individuals than other treatments. The majority of the soil macrofauna were less under continuous maize without fertilizer (Table 3). Soil macrofauna recorded in terms of species abundance, diversity and richness were significant differently $(p \leq 0.05)$ across treatments. The two-year pigeonpea fallow (T5) had highest soil macrofauna species diversity, species abundance estimate index as well as species richness as compared to treatments (Table 4). Continuous maize without fertilizer recorded the least soil macrofauna species diversity and richness while no significant difference was observed on natural fallow (T2) versus continuous maize without fertilizer and (Table 4).

Impact of pigeonpea fallows on chemical soil properties

In terms of chemical properties (Total cations, N, P, K and organic carbon) no significant difference was noted among the treatments (Table 5).

Effect of pigeonpea fallows on physical soil properties

Mean weight diameter of soil aggregates was significantly different $(p \leq 0.05)$ on the treatments at fallow termination. The highest mean weight diameter of soil aggregates at fallow termination was recorded in twoyear pigeonpea fallow (T5) while the least was found on continuous maize without fertilizer (T1). However, no significant differences were observed on two-year 
Table 3 Soil macrofauna morpho-species recorded at Fountainhill, Wartburg, South Africa after twoyears of simultaneous agroforestry system (improved fallows)
$\mathrm{T} 1$ = continuous maize without fertilizer (control), $\mathrm{T} 2$ = Natural fallow,

\section{$\mathrm{T} 3=$ Panicum}

maximum + pigeonpea followed by pigeonpea, $\mathrm{T} 4=$ maize + pigeonpea followed by pigeonpea, $\mathrm{T} 5$ = two-year pigeonpea fallow,

\begin{tabular}{|c|c|c|c|c|c|c|}
\hline Common name & Morpho-species & T5 & $\mathrm{T} 4$ & $\mathrm{~T} 3$ & $\mathrm{~T} 2$ & $\mathrm{~T} 1$ \\
\hline Earthworms & Oligochaeta sp.1 & 24 & 5 & 3 & 0 & 0 \\
\hline Earthworms & Oligochaeta sp.2 & 13 & 0 & 0 & 8 & 0 \\
\hline Earthworms & Oligochaeta sp.3 & 7 & 1 & 4 & 3 & 0 \\
\hline Bug & Cydnidae sp.1 & 2 & 2 & 1 & 4 & 0 \\
\hline Ants & Camponotus sp.1 & 55 & 11 & 10 & 29 & 0 \\
\hline Ants & Crematogaster sp. 1 & 0 & 0 & 6 & 0 & 0 \\
\hline Ants & Pheidole sp.2 & 120 & 20 & 156 & 0 & 43 \\
\hline Beetle & Chrysomelidae sp.2 & 0 & 0 & 1 & 0 & 0 \\
\hline Beetle & Tenebrionidae sp.1 & 0 & 2 & 0 & 2 & 0 \\
\hline Beetle & Tenebrionidae sp. 2 & 7 & 0 & 0 & 2 & 1 \\
\hline Beetle & Tenebrionidae sp. 3 & 2 & 0 & 1 & 0 & 0 \\
\hline Beetle & Tenebrionidae sp.4 & 4 & 0 & 1 & 0 & 0 \\
\hline Beetle larvae & Scarabaeidae sp.1 & 12 & 1 & 0 & 1 & 2 \\
\hline Millipede & Diplopoda sp.1 & 0 & 1 & 0 & 1 & 1 \\
\hline Millipede & Diplopoda sp.2 & 1 & 0 & 0 & 0 & 0 \\
\hline Millipede & Diplopoda sp.3 & 3 & 0 & 0 & 0 & 0 \\
\hline Millipede & Diplopoda sp.4 & 2 & 0 & 2 & 0 & 0 \\
\hline Ant & Technomyrmex sp.1 & 136 & 26 & 0 & 0 & 15 \\
\hline Butterfly larvae & Lepidoptera sp.1 & 0 & 1 & 0 & 0 & 0 \\
\hline Cocoon & Lepidoptera sp.2 & 2 & 1 & 1 & 0 & 0 \\
\hline Larvae of Lepidoptera & Lepidoptera sp.3 & 10 & 0 & 1 & 0 & 0 \\
\hline Larvae of Lepidoptera & Lepidoptera sp.4 & 2 & 0 & 0 & 0 & 0 \\
\hline Larvae of Lepidoptera & Lepidoptera sp.5 & 15 & 0 & 0 & 0 & 0 \\
\hline Larvae of Lepidoptera & Lepidoptera sp.6 & 1 & 0 & 0 & 0 & 0 \\
\hline Beetle larvae & Coleoptera sp.1 & 0 & 1 & 0 & 0 & 1 \\
\hline Beetle larvae & Coleoptera sp.2 & 0 & 3 & 0 & 3 & 0 \\
\hline Beetle larvae & Coleoptera sp. 3 & 0 & 1 & 0 & 1 & 0 \\
\hline Beetle larvae & Coleoptera sp.4 & 1 & 0 & 0 & 0 & 0 \\
\hline Beetle larvae & Coleoptera sp.5 & 1 & 0 & 0 & 0 & 0 \\
\hline Centipede & Chilopoda sp.1? & 2 & 2 & 0 & 2 & 0 \\
\hline Woodlouse & Oniscidea sp.1 & 1 & 0 & 2 & 0 & 2 \\
\hline Bugs & Delphacidae sp.1 & 0 & 0 & 0 & 2 & 0 \\
\hline Termite & Termitidae sp.1 & 25 & 0 & 0 & 0 & 13 \\
\hline Ant & Myrmicaria sp.1 & 0 & 1 & 0 & 0 & 0 \\
\hline Bug & Hemiptera sp.1 & 0 & 1 & 0 & 1 & 0 \\
\hline Bug & Hemiptera sp.2 & 1 & 0 & 0 & 0 & 0 \\
\hline Termite & Rhinotermitidae sp.1 & 0 & 0 & 0 & 0 & 1 \\
\hline Spider & Arachnida sp.2 & 10 & 0 & 1 & 0 & 0 \\
\hline Cricket & Gryllidae sp.1 & 0 & 0 & 1 & 0 & 0 \\
\hline \multirow[t]{2}{*}{ Beetle } & Meloidae sp.1 & 458 & 1 & 191 & 77 & 59 \\
\hline & Total (individuals) & 917 & 81 & 382 & 136 & 138 \\
\hline
\end{tabular}

pigeonpea versus pigeonpea + maize then pigeonpea (T4) and pigeonpea + P.maximum then pigeonpea (T3). (Table 6) Aggregate stability decreased as shown; T5 $>$ T4 $\geq$ T3 $\geq$ T2 $>$ T1 (Table 6). Similar trend was observed with infiltration rate with two-year pigeonpea fallow (T5) significantly higher than all the 
Table 4 Pigeonpea improved fallows effect on soil macrofauna indices: Numbers followed by same letters are not significantly different at $p \leq 0.05$ according to Tukey's Honest Significant Difference Test

\begin{tabular}{llll}
\hline Treatments & Mean species diversity index $\left(\mathrm{H}^{\prime}\right)$ & Mean species richness index $\left(\mathrm{H}^{\prime}\right)$ & Mean species abundance estimate index $\left(\mathrm{H}^{\prime}\right)$ \\
\hline T1 & $0.98 \mathbf{a}$ & $6.00 \mathbf{a}$ & $12.01 \mathbf{a}$ \\
$\mathrm{T} 2$ & $1.66 \mathbf{b}$ & $9.67 \mathbf{b}$ & $19.72 \mathbf{a}$ \\
$\mathrm{T} 3$ & $0.78 \mathbf{a}$ & $10.56 \mathbf{b c}$ & $23.62 \mathbf{a b}$ \\
$\mathrm{T} 4$ & $1.62 \mathbf{b}$ & $13.33 \mathbf{c}$ & $11.95 \mathbf{a}$ \\
T5 & $1.66 \mathbf{b}$ & $17.44 \mathbf{d}$ & $44.84 \mathbf{c}$ \\
$\mathrm{p}-$ value & $<.001$ & $<.001$ & $<.001$ \\
CV & 13.0 & 16.3 & 25.8 \\
\hline
\end{tabular}

$\mathrm{T} 1$ = continuous maize without fertilizer (control), $\mathrm{T} 2=$ Natural fallow, $\mathrm{T} 3=$ Panicum maximum + pigeonpea followed by pigeonpea, $\mathrm{T} 4=$ maize + pigeonpea followed by pigeonpea, $\mathrm{T} 5=$ two-year pigeonpea fallow, $\mathrm{CV}=\mathrm{Coefficient}$ of variation

Table 5 Effects of two-year improved pigeonpea fallows on chemical soil properties

\begin{tabular}{lllllll}
\hline Treatments & $\mathrm{N}(\%)$ & $\mathrm{P}\left(\mathrm{g} \mathrm{kg}^{-1}\right)$ & $\mathrm{K}\left(\mathrm{mg} \mathrm{kg}^{-1}\right)$ & Org C $(\%)$ & Total Cations $\left(\mathrm{c} \mathrm{mol} \mathrm{kg}^{-1}\right)$ & $\mathrm{pH}(\mathrm{KCI})$ \\
\hline TI & 0.12 & 20.67 & 72.0 & 0.73 & 2.36 & 3.89 \\
T2 & 0.08 & 23.33 & 115.7 & 0.90 & 3.33 & 4.46 \\
T3 & 0.12 & 25.00 & 108.0 & 1.28 & 3.14 & 4.27 \\
T4 & 0.18 & 20.00 & 117.0 & 1.10 & 3.76 & 4.67 \\
T5 & 0.11 & 21.33 & 172.0 & 1.13 & 5.05 & 4.79 \\
HSD (0.05) & 0.09 & 8.51 & 67.97 & 1.06 & 1.98 & 0.754 \\
p-value & 0.16 & 0.66 & 0.09 & 0.71 & 0.11 & 0.133 \\
CV & 31 & 20.5 & 30.9 & 49.2 & 29.8 & 9.1 \\
\hline
\end{tabular}

$\mathrm{T} 1=$ continuous maize without fertilizer $($ control), $\mathrm{T} 2=$ Natural fallow, $\mathrm{T} 3=$ Panicum maximum + pigeonpea then pigeonpea, $\mathrm{T} 4=$ maize + pigeonpea then pigeonpea, $\mathrm{T} 5=$ two-year pigeonpea fallow, $\mathrm{CV}=$ Coefficient of variation

Table 6 Soil physical properties at Fountainhill Estate after two-year pigeonpea fallow; Numbers followed by same letters are not significantly different at $\mathrm{p} \leq 0.05$ according to Tukey's test

\begin{tabular}{llll}
\hline Treatments & Aggregate stability $(\mathrm{mm})$ & Bulk density $\left(\mathrm{g} \mathrm{cm}^{-3}\right)$ & Infiltration rate $(\mathrm{mm}$ hr \\
\hline T1 & $5.02 \mathbf{a}$ & $1.46 \mathbf{b}$ & $12.44 \mathbf{a}$ \\
T2 & $8.99 \mathbf{b}$ & $1.43 \mathbf{b}$ & $19.11 \mathrm{ab}$ \\
T3 & $10.13 \mathbf{b c}$ & $1.26 \mathbf{a}$ & $20.99 \mathbf{b}$ \\
T4 & $11.20 \mathbf{c}$ & $1.36 \mathbf{a b}$ & $15.97 \mathbf{a b}$ \\
T5 & $11.45 \mathbf{c}$ & $1.22 \mathbf{a}$ & $29.81 \mathbf{c}$ \\
HSD $(0.05)$ & 1.604 & 0.15 & 7.47 \\
p-value & $<.001$ & 0.015 & 0.006 \\
CV & 14.4 & 9.4 & 20.2
\end{tabular}

$\mathrm{T} 1=$ continuous maize without fertilizer $($ control), $\mathrm{T} 2=$ Natural fallow, $\mathrm{T} 3=$ Panicum maximum + pigeonpea then pigeonpea, $\mathrm{T} 4=$ maize + pigeonpea then pigeonpea, $\mathrm{T} 5=$ two-year pigeonpea fallow, $\mathrm{CV}=$ Coefficient of variation 
Table 7 Maize yields affected by improved fallows yield and pigeonpea leaf litter $\left(\mathrm{kg} \mathrm{ha}^{-1}\right)$; numbers followed by same letters are not significantly different at $\mathrm{p} \leq 0.05$ according to Tukey's Honest Significant Difference Test

\begin{tabular}{|c|c|c|c|}
\hline \multirow[t]{2}{*}{ Treatments } & \multicolumn{3}{|c|}{ Yield $\left(\mathrm{kg} \mathrm{ha}^{-1}\right)$} \\
\hline & Grain & Stover & Pigeonpea leaf litter \\
\hline $\mathrm{T} 1$ & $993 \mathbf{a}$ & $1021 \mathbf{a}$ & $*$ \\
\hline $\mathrm{T} 2$ & $2294 \mathbf{b}$ & $1578 \mathbf{b}$ & $*$ \\
\hline $\mathrm{T} 3$ & $2852 c$ & $2264 c$ & $4766 \mathbf{a}$ \\
\hline $\mathrm{T} 4$ & $2922 \mathrm{c}$ & $2125 \mathrm{c}$ & $5445 \mathbf{a}$ \\
\hline T5 & $3787 \mathbf{d}$ & $3104 d$ & $7323 \mathbf{b}$ \\
\hline $\operatorname{HSD}_{(0.05)}$ & 514 & 451.6 & 1282 \\
\hline p-value & $<.001$ & $<.001$ & 0.012 \\
\hline $\mathrm{CV}$ & 10.6 & 11.9 & 9.7 \\
\hline \multicolumn{4}{|c|}{$\begin{array}{l}\mathrm{T} 1=\text { continuous maize without fertilizer (control), } \\
\mathrm{T} 2=\text { Natural fallow, } \mathrm{T} 3=\text { Panicum maximum }+ \text { pigeonpea } \\
\text { followed by pigeonpea, } \mathrm{T} 4=\text { maize }+ \text { pigeonpea followed by } \\
\text { pigeonpea, } \mathrm{T} 5=\text { two-year pigeonpea fallow, } \mathrm{CV}=\text { Coefficient } \\
\text { of variation, * no data }\end{array}$} \\
\hline
\end{tabular}

treatments, meanwhile the least infiltration rate was experienced on continuous maize without fertilizer. Pigeonpea + maize then pigeonpea (T4) had almost similar value with natural fallow and both were not significantly different with pigeonpea $+P$. maximum then pigeonpea (T3). Bulk density was significantly differently $(\mathrm{p} \leq 0.05)$ affected by cropping system after two-year pigeonpea fallow termination (Table 6). The bulk density was lowest under two-year pigeonpea fallow and pigeonpea $+P$. maximum then pigeonpea (T3) plots as compared to continuous maize without fertilizer (T1) and natural fallow (T2). However maize + pigeonpea then pigeonpea (T4) did show significant difference with other treatments. The values ranged from 1.22 to $1.46 \mathrm{~g} \mathrm{~cm}^{-3}$ for two-year pigeonpea fallow and continuous maize without fertilizer, respectively.

Pigeonpea leaf litter and maize yields

Pigeonpea leaf litter fall accumulation and both maize grain and stover yield was significantly different ( $p<0.001)$. Two-year pigeonpea fallow (T5) had the highest leaf litter as compared to both intercrops (T3 and T4), while no significant different were observed between T4 and T3. Maize grain and stover yield differ significantly $(p<0.001)$ between the treatments. Grain and stover yields were 3 times higher in two-year pigeonpea fallow plots (T5) than continuous maize without fertilizer plots (T1). No significant different was noticed on pigeonpea + maize then pigeonpea (T4) and pigeonpea + P.maximum then pigeonpea (T4) (Table 7).

Biological and physical soil properties and relationship with maize grain yield

Soil macrofauna estimate species abundance, species diversity, species richness, aggregate stability, bulk density and infiltration rate presented significant correlations with maize yield (Table 8). Soil macrofauna species diversity recorded the highest significant $(p<0.001)$ positive correlation with maize grain yield while bulk density had the least significant correlation.
Table 8 Pearson correlation coefficients ( $r$ ) for grain yield and six soil physical properties and macrofauna indices $* p<0.05$, $* * p<0.01, * * * p<0.001$, NS = not significant, GY = Grain yield, $\mathrm{BD}=$ Bulk density, AG = Aggregate stability, IR = infiltration rate $\mathrm{SR}=$ Species richness, $\mathrm{SD}=$ Species diversity, $\mathrm{AB}=$ abundance and $\mathrm{LL}=$ Leaf litter

\begin{tabular}{llllllll}
\hline & $\mathrm{GY}$ & $\mathrm{AB}$ & $\mathrm{SD}$ & $\mathrm{SR}$ & $\mathrm{AG}$ & $\mathrm{BD}$ & $\mathrm{IR}$ \\
\hline $\mathrm{GY}$ & 1 & $0.75^{* * *}$ & $0.9 * * *$ & $0.83^{* *}$ & $0.82^{* * *}$ & $-0.63^{*}$ & $0.77^{* * *}$ \\
$\mathrm{AB}$ & $0.75^{* * *}$ & 1 & $0.82^{* * *}$ & $0.58^{*}$ & $0.66^{* *}$ & $-0.71^{* *}$ & $0.45 \mathrm{~ns}$ \\
$\mathrm{SD}$ & $0.9 * * *$ & $0.82^{* *}$ & 1 & $0.85^{* *}$ & $0.8 * *$ & $-0.58 \mathrm{NS}$ & $0.82^{* *}$ \\
$\mathrm{SR}$ & $0.83^{* *}$ & $0.58^{*}$ & $0.85^{* *}$ & 1 & $0.63 *$ & $-0.43 \mathrm{NS}$ & $0.68^{* *}$ \\
$\mathrm{AG}$ & $0.82^{* * *}$ & $0.66^{* *}$ & $0.8^{* *}$ & $0.63^{*}$ & 1 & $-0.72 * *$ & $0.64 *$ \\
$\mathrm{BD}$ & $-0.63^{*}$ & $-0.71^{* *}$ & $-0.58 \mathrm{NS}$ & $0.43 \mathrm{NS}$ & $-0.72^{* *}$ & 1 & $-0.37 \mathrm{NS}$ \\
$\mathrm{IR}$ & $0.77 * * *$ & $0.45 \mathrm{NS}$ & $0.82^{* * *}$ & $0.68^{*}$ & $0.64 *$ & $-0.37 \mathrm{NS}$ & 1 \\
\hline
\end{tabular}




\section{Discussion}

The effect of improved pigeonpea fallows on soil biological soil properties can be assessed by changes in soil macrofauna species abundance, diversity and richness. The study has shown that the majority of the soil macrofauna were less abundant under maize + pigeonpea then pigeonpea (T4), natural fallow (T2) and continuous maize without fertilizer (T1), which represents mechanical and physical disturbance through weeding, low quality food reserves (Aragrostis curvula, Bidens pilosa and Cynodon dactylon) and direct sunlight since the grasses were sparsely distributed and agricultural intensification involving continuous cropping. Our study agrees with Sileshi and Mafongoya (2006) where maize grown after Gliricidia sepium or Leucaena leucocephala recorded higher soil macrofauna abundance than continuous sole maize. The difference was attributed to the presence of canopy layer throughout the season and presence leaf litter which act as food reserves than intensive monoculture which leaves the soil unprotected. Two-year pigeonpea fallow (T5) outperformed all the treatments in terms of soil macrofauna species abundance and richness excluding diversity on natural fallow (T2). These observed variations in macrofauna diversity, richness and abundance seem to be related with management practices such as modification of soil microclimate within these treatment compositions and availability of food sources for the associated macrofauna groups. Management practices which include fallowing, monoculture, crop rotation and leaf litter addition have been shown to be among the causes of the alterations of soil macrofauna population structure, vanishing or declining of major species and in some instances exceedingly low abundances (Ayuke et al. 2011; Paul et al. 2013). These observations are consistent with results of our study, in which soil macrofauna mean estimate species abundance, species diversity, species richness were found to be higher in two-year pigeonpea fallow (T5) but low in continuous maize without fertilizer (T1), Panicum maximum + pigeonpea then pigeonpea (T3) and maize + pigeonpea then pigeonpea (T4). Litter layer is a very essential factor in enhancing soil temperature and soil moisture content, consequently creating a more favourable environment for both litter and soildwelling macrofauna. This may explain the expected higher macrofauna diversity, richness and abundance observed in treatments containing pigeonpea leaf litter although there were some variations among those treatments.

Microclimate factors which include low soil temperature and higher soil water content, well-developed leaf litter layer and less human interference promotes the soil macrofauna to survive on pigeonpea fallows than in sole continuous maize without fertilizer. Enhanced leaf litter and reduction in soil moisture, often results in reduced soil macrofauna abundance and diversity (Prates et al. 2011; Urbanovicova et al. 2014). Probable this might be the reason behind the lower soil macrofauna abundance and diversity on P.maximum + pigeonpea then pigeonpea. Cole et al. (2006) found that physical soil disturbances could, to some extent, be of more relevant in controlling the quantity of some soil macrofauna than the presence of food resources. This might be the possible reason why there was no significant difference in terms mean species diversity between continuous maize without fertilizer (T1) and $P$. maximum + pigeonpea then pigeonpea (T3) even though the latter had leaf litter the mechanical disturbance by removing P.maximum might probable have negative effect. Soil macrofauna is known to enhance physical soil properties such as aggregate, infiltration rate and lowering bulk density (Sileshi and Mafongoya 2006; Blanchart et al. 2009; Castellanos-Navarrete et al. 2012; Paul et al. 2015).

Soil aggregate stability, bulk density and infiltration rate are most commonly used indicators of physical soil properties (Sileshi et al. 2014). Physical soil properties are essential indicators to assess agricultural management practices (Yang et al. 2012). This study showed that continuous maize without (T1) fertilizer and natural fallow (T2) recorded the highest soil bulk density. Two-year improved pigeonpea fallows and Panicum maximum + pigeonpea then pigeonpea recorded the least as compared to all the treatments. The soil bulk density decreased under two-year improved pigeonpea fallow and Panicum maximum + pigeonpea then pigeonpea might have been attributed to higher leaf litter addition from pigeonpea legume trees (Sarvade et al. 2014). However, maize + pigeonpea then pigeonpea (T4) did not show significant difference. The higher bulk density under two-year continuous maize cropping system without fertilizer (T1) and natural fallow (T2) might have been caused by the absence of high organic 
matter on soil surface however, presence of pigeonpea leaf litter on two-year fallow tend to lower bulk density. These results from the study are partly in accordance with (Amusan et al. 2006; Ramesh et al. 2013) where they found bulk density of cacao agroforestry plantation $\left(1.32 \mathrm{~g} \mathrm{~cm}^{-3}\right)$ was generally significantly lower than natural forest $\left(1.49 \mathrm{~g} \mathrm{~cm}^{-3}\right)$ and $7 \%$ reduction in bulk density than the control plot (without tree plantation) respectively.

Soil aggregate stability is described as the ability of soil to remain intact when put through some stress (Wick et al. 2009). Soil aggregate stability can be affected by land management and correspond well with soil erodibility. Hence it is extensively applied as soil degradation indicator (Wick et al. 2009; Fonte et al. 2014). Highest mean weight diameter of soil aggregates on two-year pigeonpea fallow (T5), maize + pigeonpea then pigeonpea (T4) and grass + pigeonpea then pigeonpea (T3) at both fallow terminations might have been caused by the quantity of leaf litter than continuous maize without fertilizer (T1).Two-year improved pigeonpea fallow recorded highest leaf litter as compared to other treatments, while the absence of leaf litter on continuous maize plots led to lowest aggregate stability. In Zimbabwe and Zambia, soil aggregate stability on sesbania and pigeonpea fallows was higher as compared to continuous sole maize crop (Chirwa et al. 2004; Nyamadzawo et al. 2007). In another studies, conducted by Mostafa et al. (2008) and Lawal et al. (2009) they reported higher aggregate stability in soils of agroforestry systems than soils cultivated annual crops. Natural grass fallow (T2) had higher soil aggregate as compared to continuous maize without fertilizer this might be due to lower soil disturbance on natural fallow than continuous cultivation which destroys soil structure. This study agreed with Somasundaram et al. (2012) reported that natural grass fallow had greater aggregate stability ( $>5 \mathrm{~mm}$ ) as compared to continuous cultivated fields, which recorded lowest aggregates in India. Infiltration rate is defined as the rate at which water moves into the soil per unit time. Direct impact of rain drops clogs the pores and causes surface sealing which reduce the infiltration and cause runoff which will lead to soil erosion. Leaf litter cover over the soil surface hinders direct impact of rain drops and reduces the chance of erosion through increasing water infiltration. Higher infiltration was observed on two-year pigeonpea (T5) as compared to other treatments which can be attributed to higher quantity of leaf litter of pigeonpea. While the least infiltration rate was recorded on continuous maize without fertilizer (T1) which might have been caused by direct impact of rain drops which tend to induce soil surface sealing which will lead to infiltration rate. Better soil aggregation improves soil water infiltration by reducing soil erosion (Saha et al. 2010). Decomposition of herbaceous legume roots tend to improve infiltration rate, soil aggregation and lowering of soil bulk density (Sheoran et al. 2010).

The absence of significant differences were observed on chemical soil properties $(\mathrm{pH}, \mathrm{N}, \mathrm{P}, \mathrm{K}$ and organic carbon) after two-year pigeonpea fallows the possible reason is the duration of fallows, which was too short to effect changes. A study conducted by Diekow et al. (2005) in Brazil, increase in soil C stocks by $26 \%$ was only recorded after 17 years of maizepigeonpea cropping systems. Chirwa et al. (2006) found similar results with our study where no significant change in SOC was recorded when pigeonpea was integrated in agroforestry systems. In other similar studies carried out by Adu-Gyamfi et al. (2007) in Malawi and Tanzania no significant change in total soil $\mathrm{C}$ after two seasons of maize-pigeonpea intercropping in Malawi and Tanzania. They attributed to low quantity leaf biomass returned to the soil. Hence the leaf litter quantity produced by fallows might not be enough or might not have decomposed to effect the changes.

Research work done in eastern Zambia has shown that, improved fallows could revamp physical soil properties thereby increasing maize yields (Chirwa et al. 2004). Hamza and Anderson (2005) reported that increases in bulk density can subsequently lead low maize yield. This might be the reason in contrasting yield differences in both grain and stover yield in this study. Constant litter fall on improved fallows led to the improvement in biological and physical soil properties. Maize yield was greatest in two-year pigeonpea fallow treatment as compared to all other treatments. Two-year pigeonpea fallow treatment had also the highest leaf litter produced during fallow period. The sole two-year pigeonpea fallow (T5) out yielded the intercrops which included maize (T4) and P.maximum grass (T3) in the first season. Competition among light, soil nutrients and moisture during establishment season could be the possible reason in differences of leaf litter on intercrops (Yun et al. 
2012). Nitrogen input from biological nitrogen fixation (BNF) from roots and nodules could have enhanced mineralization that might have improved maize and stover yields (Mafongoya and Dzowela 1999; Rao et al. 1998). Maize following two-year pigeonpea fallows produced 3.2 times higher grain yield as compared maize without fertilizer. Egbe et al. (2007) had reported better performance of maize planted on previous pigeonpea plots and attributed such increases to higher levels of $\mathrm{N}$ fixed in the pigeonpea plots as compared to the natural fallow. In another study, Njira et al. 2017 reported that sole pigeonpea fixed $92.9 \mathrm{~kg} \mathrm{~N} \mathrm{ha}^{-1}$ as compared $59.9 \mathrm{~kg} \mathrm{~N} \mathrm{ha}^{-1}$ ) which was recorded on pigeonpea intercropped with maize, this might be reason our study recorded highest stover and grain maize yield as compared to maize grown on $\mathrm{T} 3$ and $\mathrm{T} 4$ treatments. The lower N on T3 and T4 plots which might have been fixed through BNF may have contributed to higher maize yields produced as compared to continuous maize without fertilizer (T1) and maize grown on natural fallow (T2). The differences in maize response on contrasting fallow systems might have been also ascribed to the differences in species diversity and richness, aggregate stability, bulk density and infiltration rate. During decomposition process, soil macro fauna facilitates the mineralization of organic forms of nutrients in the pigeonpea leaf litter (Susilo et al. 2004) which can be absorbed by the maize crop thereby increasing yields. The availability of soil macrofauna and decomposition of tree roots were found to leave channels which further increases infiltration into soil thereby increasing soil water storage (Blanchart et al. 2004). Soil water storage is essential attribute in agricultural sustainability under climate change variability (Sileshi and Mafongoya 2006). The study agreed with Abunyewa and Karbo (2005), found that maize yields increased after two-years of pigeonpea fallows as compared to continuous monocropping without fertilizer. Nyamadzawo et al. (2012) also found that improved fallowing increased yields as compared to natural fallow which agreed with our findings both pigeonpea fallows out yielded a natural fallow. In a meta-analysis conducted by Sileshi et al. (2008a), increase in maize yield when legume trees such as pigeonpea when used as fallows is attributed to $\mathrm{N}$ input by BNF, retrieval of nutrients from below rooting maize crops, reduction in nutrient losses from leaching, runoff and erosion and improved soil water conditions. Pigeonpea fallows improved biological and physical soil properties thereby increasing maize yield.

Soil macrofauna is the most sensitive indicator to improved pigeonpea fallows land use which can be used to predict the quality of the land (Rousseau et al. 2013). Species diversity had the highest significant positive correlation to maize grain yield, followed by species richness and estimate abundance species was least among soil macrofauna indices. The significant correlations between soil macrofauna indices and physical soil properties to maize grain yield shows that, besides other agronomic practices and climatic conditions, biological and physical soil properties may indirectly play a major role in determining maize yields. This indicates the potential of using soil macrofauna species richness, diversity and abundance indices and soil aggregate stability, bulk density and infiltration rate as soil indicators of soil productivity.

\section{Conclusion}

Our findings showed that pigeonpea fallows improved both biological and physical soil properties which ultimately led to increase in maize yield by 3.2 times as compared to continuous maize without fertilizer. Biological (soil macrofauna estimate species abundance, species diversity, species richness) and physical (aggregate stability, bulk density and infiltration rate) soil attributes evaluated are sensitive enough to be adopted as indicators of soil quality, and they are also related to the maize yields. Hence, study will help in providing RSA farmers and policy maker's information on sequential agroforestry systems (pigeonpea improved fallows) which can be adopted as an alternative sustainable cropping system. This sustainable farming system can also help in reducing the burden of purchasing expensive synthetic fertilizers in rural farming communities to increase crop productivity and enhance food security. Smallholders who have limited access to fertilizers can sustainably use improved pigeonpea fallows to achieve higher yields. There is need to institute a policy to scale up agroforestry to solve the challenges of degraded soils and reduce the burden of smallholder farmers of purchasing expensive inorganic fertilizers. This will ultimately increase the maize yields thereby ensuring food security in South Africa. Moreover, by 
identifying the most sensitive and responsive biological and physical soil indicators, it will be possible to improve decision-making processes regarding interventions of reducing soil degradation using sequential agroforestry stems (improved fallows). According to Ajayi et al. (2007), legume fallows such as pigeonpea fallows have greater benefit cost ratio than chemical fertilizers which implies that there is a higher return per unit investment.

Acknowledgements We are grateful to Dr Caswell Munyai of UKZN for his help on soil macrofauna identification and $\mathrm{Mr}$ Edwin Gevers Farm Manager at Fountainhill Estate for the study site.

Funding This work was supported by Water Research Commission of South Africa (WRC) under project number K5/2492//4. Titled Water use of agroforestry systems for food, forage and/or biofuel production.

\section{Compliance with ethical standards}

\section{Conflict of interest None.}

Open Access This article is licensed under a Creative Commons Attribution 4.0 International License, which permits use, sharing, adaptation, distribution and reproduction in any medium or format, as long as you give appropriate credit to the original author(s) and the source, provide a link to the Creative Commons licence, and indicate if changes were made. The images or other third party material in this article are included in the article's Creative Commons licence, unless indicated otherwise in a credit line to the material. If material is not included in the article's Creative Commons licence and your intended use is not permitted by statutory regulation or exceeds the permitted use, you will need to obtain permission directly from the copyright holder. To view a copy of this licence, visit http://creativecommons.org/licenses/by/4.0/.

\section{References}

Abunyewa AA, Karbo KN (2005) Improved fallow with pigeonpea for soil fertility improvement and to increase maize production in smallholder crop-livestock farming system in the Subhumid zone of Ghana Land. Degrad Dev $16: 447-454$

Adu-Gyamfi JJ, Myaka FA, Sakala WD, Odgaard R, Vesterager JM, Hogh-Jensen H (2007) Biological nitrogen fixation and nitrogen and phosphorus budgets in farmer-managed intercrops of maize-pigeonpea in semi-arid southern and eastern Africa. Plant Soil 295:127-213

Ajayi OC, Akinnifesi FK, Sileshi G, Chakeredza S (2007) Adoption of renewable soil fertility replenishment technologies in southern African region: lessons learnt and way forward. Nat Resour Forum 31:306-317
Amusan AA, Shitu AK, Makinde WO, Orewole O (2006) Assessment of changes in selected soil properties under different land use in Obafemi Awolowo University Community, ILE-IFE, Nigeria. Electric J Environ Agric Food Chem 5:1178-1184

Anderson JM, Ingram JSI (1993) Tropical soil biology and fertility: a handbook on methods. CAB International, Wallingford

Ayuke FO, Pulleman MM, Vanlauwe B, de Goede RGM, Six J, Csuzdi C et al (2011) Agricultural management affects earthworm and termite diversity across humid to semi-arid tropical zones. Agric Ecosyst Environ 148:148-154. https://doi.org/10.1016/j.agee.2010.11.021

Barbier E, Hochard J (2016) Poverty and the spatial distribution of rural population (Policy Research Working Paper, WPS 7101). World Bank Group., Washington, DC

Barrios E, Sileshi GW, Shepherd K, Sinclair F (2012) Agroforestry and soil health: linking trees, soil biota, and ecosystem services. In: Wall DH et al (eds) Soil ecology and ecosystem services. Oxford University Press, Oxford, pp 315-330

Bationo A, Waswa BS (2011) New challenges and opportunities for integrated soil fertility management in Africa. In: Bationo A, Waswa B, Okeyo JM, Maina F, Kihara J (eds) Innovation as key to the green revolution in Africa: exploring the scientific facts, vol 1. Springer, New York, pp 3-17

Blanchart E, Albrecht A, Brown G, Decaens T, Duboisset A, Lavelle P, Mariani L, Roose E (2004) Effects of tropical endogeic earthworms on soil erosion. Agric Ecosyst Environ 104:303-315

Bremner JM, Mulvaney CS (1982) Nitrogen-total. In: Page AL, Miller RH, Keeney DR (eds) Methods of soil analysis, Part 2: chemical and microbiological properties, 2nd edn. Soil Science Society of America, New York, pp 595-624

Castellanos-Navarrete A, Rodríguez-Aragonés C, de Goede RGM, Kooistra MJ, Sayre KD, Brussaard L et al (2012) Earthworm activity and soil structural changes under conservation agriculture in Mexico. Soil Till Res 123:61-70. https://doi.org/10.1016/j.still.2012.03.011

Chapman HD, Pratt FP (1965) Ammonium vanadate-molybdate method for determination of phosphorus. In: Agriculture D (ed) Methods of analysis for soils, plants and water, 1st. California University, Oakland, pp 184-203

Chirwa TS, Mafongoya PL, Mbewe DNM, Chishala BH (2004) Changes in soil properties and their effects on maize productivity following Sesbania sesban and Cajanus cajan improved fallow systems in eastern Zambia. Biol Fert Soils 40:20-27

Chirwa PW, Black CR, Ong CK, Maghembe J (2006) Nitrogen dynamics in cropping systems in southern Malawi containing Gliricidia sepium, pigeonpea and maize. Agrofor Syst 67:93-106

Choudhury SG, Srivastava S, Singh R, Chaudhari SK, Sharma DK, Singh SK, Sarkar D (2014) Tillage and residue management effects on soil aggregation, organic carbon dynamics and yield attribute in rice-wheat cropping system under reclaimed sodic soil. Soil Till Res 136:76-83

Cole L, Bradford MA, Shaw PJA, Bardgett RD (2006) The abundance, richness and functional role of soil meso- and 
macrofauna in temperate grassland: a case study. Appl Soil Ecol 33:186-198

Dangerfield JM (1997) Characterization of soil fauna communities. In: Rao MR, Schole SRJ (eds) Report on characterization of experimental field in KARI Farm, Muguga, Kenya. ICRAF, Nairobi, Kenya

Diekow J, Mielniczuk J, Knicker H, Bayer C, Dick DP, KogelKnabner I (2005) Soil C and N stocks as affected by cropping systems and nitrogen fertilization in a southern Brazil acrisol managed under no-tillage for 17 years. Soil Till Res 81:87-95

Drechsel P, Gyiele L, Kunze D, Cofie O (2001) Population density, soil nutrient depletion, and economic growth in sub-Saharan Africa. Ecosystem 38:251-258

Egbe OM, Idoga S, Idoko JA (2007) Preliminary investigation of residual benefits of pigeonpea genotypes intercropped with maize in Southern Guinea Savanna of Nigeria. J Sustain Dev Agric Environ 3:58-75

Everson C, Ghehezi S, Everson TM, Annandale J (2011) Agroforestry systems for improved food production through the efficient use of water. Final report for WRC Project No. K5/1480, presented at WRC Reference Group Meeting, 16 November 2011. Water Research Commission, Pretoria, South Africa

Faye M (2010) Soils of South Africa. Cambridge University Press, Cape Town, South Africa, p 287

Félix GF, Scholberg JMS, Clermont-Dauphin C, Tittonell CLP (2018) Enhancing agroecosystem productivity with woody perennials in semi-arid West Africa: a meta-analysis. Agron Sustain Dev 38:57. https://doi.org/10.1007/s13593018-0533-3

Fonte SJ, Nesper M, Hegglin D, Velásquez JE, Ramirez B, Rao IM, Bernasconi SM, Büneman EK, Frossard E, Oberson A (2014) Pasture degradation impacts soil phosphorus storage via changes to aggregate-associated soil organic matter in highly weathered tropical soils. Soil Biol Biochem 68:150-157

Gwirtz JA, Garcia-Casal MN (2014) Processing maize flour and corn meal food products. Ann N Y Acad Scis 1312(1):66-75

Hamza MA, Anderson W (2005) Soil compaction in cropping systems: a review of the nature, causes and possible solutions. Soil Till Res 82(2):121-145

Hluyako LL, Odindo A, Mafongoya P, Magwaza SNJ, LS, (2017) Characterisation of pigeon pea (Cajanus cajan) landraces grown in two climatic zones in KwaZulu-Natal province, South Africa. S Afr J Plant Soil 34:191-199

International Institute of Tropical (IITA) (1979) Selected methods for soil and plant analysis. Manual Series No. 1, pp 3, 6-7, 10-12, 14-15. Ibadan, Nigeria

Josephson AL, Ricker-Gilbert J, Florax R (2014) How does population density influence agricultural intensification and productivity? Evidence from Ethiopia. Food Policy 48:142-152

Kihara J, Nziguheba G, Zingore S, Coulibaly A, Esilaba A, Kabambe V, Huising J (2016) Understanding variability in crop response to fertilizer and amendments in sub-Saharan Africa. Agric Ecosyst Environ 229:1-12

Kogbe JOS, Adediran JA (2003) Influence of nitrogen, phosphorus and potassium application on the yield of maize in the savannah zone of Nigeria. Afr J Biotechnol 2:345-349
Kwena K, Ayuke FO, Karuka GN, Esilaba AO (2017) The curse of low soil fertility and diminishing maize yields in semiarid Kenya:Can pigeonpea play savior? Trop Subtrop Agroecosyst 20:263-278

Lal R, Kimble JM (2001) Importance of soil bulk density and methods of its importance. In: Lal R, Kimble JM, Follett RF, Stewart BA (eds) Assessment Methods for Soil Carbon. Lewis Publishers, London

Lavelle P, Senapati B, Barros E (2003) Soil macrofauna. In: Scroth G, Sinclair FL (eds) Trees, Crops and Soil Fertility: Concepts and Research Methods. CAB International, Wallingford

Lawal HM, Ogunwole JO, Uyovbisere EO (2009) Changes in soil aggregate stability and carbon sequestration mediated by land use practices in a degraded dry savanna. Alfisol Trop Subtrop Agroecosyst 10:423-429

Mafongoya PL, Dzowela BH (1999) Biomass production of tree fallows and their residual effect on maize in Zimbabwe. Agrofor Syst 47:139-151

Mafongoya PL, Jiri O (2016) Soil nitrogen and physical properties and maize yields after mixed planted fallows of tree and herbaceous legumes. Nutr Cycling Agroecosyst. https://doi.org/10.1007/s10705-016-9776-Z

Mafongoya PL, Kuntashula E, Sileshi G (2006) Managing soil fertility and nutrient through fertilizer trees in southern Africa. In: Uphoff N, Ball AS, Fernandes E, et al (eds) Biological approaches to sustainable soil systems. Taylor \& Francis, pp 273-289

Mamuye M, Nebiyu A, Elias E, Berecha G (2020) Short-term improved fallows of Tephrosia vogelii and Cajanus cajan enhanced maize productivity and soil chemical properties of a degraded fallow land in Southwestern Ethiopia. Agrofor Syst. https://doi.org/10.1007/s10457-020-00485-7

Manyanga MA, Mafongoya PL, Tauro TP (2014) Soil macrofauna diversity and abundance order under improved fallows and organic matter transfer system in Zimbabwe. Africa J Ecol 52(4):506-513

Marsden C, Martin-Chave A, Cortet J, Hedde M, Capowiez Y (2019) How agroforestry systems influence soil fauna and their functions: a review. Plant Soil. https://doi.org/10. 1007/s11104-019-04322-4

Mashingaidze K (2006) Farmer-participatory maize (Zea mays L.) cultivar evaluation and selection in Eastern Cape Province of South Africa. Paper presented at the 2006 International Plant Breeding Symposium, 20-25 August 2006, Mexico City, Mexico

Montanari R, Carvalho MP, Andreotti M, Dalchiavon FC, Lovera LH, Honorato MAO (2010) Aspectos da produtividade do feijão correlacionados com atributos físicos do solo sob elevado nível tecnológico de manejo. J Soil Sci 34:1811-1822

Mostafa E, Mehdi E, Majid B, Hamed F, Mehboub S (2008) Effect of land use change on selected soil physical and chemical properties in North Highlands of Iran. J Appl Sci 8(3):496-502. https://doi.org/10.3923/jas.2008.496.502

Munthali MG, Gachene CKK, Gudeta WS, Nancy KK (2014) Amendment of Tephrosia improved fallows with inorganic fertilizers improves soil chemical properties, $\mathrm{N}$ uptake, and maize yield in Malawi. Int J Agron. https://doi.org/10. $1155 / 2014 / 902820$ 
Musokwa M, Mafongoya P, Lorentz S (2019) Evaluation of agroforestry systems for maize (Zea mays) productivity in South Africa. South Africa J Plant Soil 36(1):65-67

Nelson EW, Sommers LE (1982) Total Carbon, Organic Carbon, and Organic Matter. In: Page AL, Miller RH, Keeney DR (eds) Methods of soil analysis: chemical methods. Part 3. Soil Science Society of America, Madison, pp 542-560

Njira KOW, Semu E, Mrema JP, Nalivat PC (2017) Biological nitrogen fixation by pigeonpea and cowpea in the " doubled- up and other cropping systems on the Luvisols of Central Malawi. Africa J Agric Res 12(15):1341-1352

Nyamadzawo G, Nyamugafata P, Chikowo R, Giller K (2007) Residual effects of fallows on selected soil hydraulic properties in a kaolinitic soil subjected to conventional tillage (CT) and no tillage (NT). Agrofor Syst 72:161-168

Nyamadzawo G, Nyamugafata P, Wuta M, Nyamangara J (2012) Maize yields under coppicing and non-coppicing fallows in a fallow-maize rotation system in central Zimbabwe. Agrofor Syst 84:273-286

Olsen SR, Sommers LE (1982) Phosphorus. In: Page AL, Miller RH, Keeney DR (eds) Methods of soil analysis, part 2-chemical and microbiological properties, 2nd edn. Soil Science Society of America, New York, pp 403-427

Paul BK, Vanlauwe B, Ayuke FO, Gassnerc A, Hoogmoed M, Hurissoa TT, Koala S, Lelei D, Ndabamenyea T, Six J, Pulleman MM (2013) Medium-term impact of tillage and residue management on soil aggregate stability, soil carbon and crop productivity. Agric Ecosyst Environ 164:14-22

Paul BK, Vanlauwe B, Hoogmoed M, Hurisso TT, Ndabamenye T, Terano Y et al (2015) Exclusion of soil macrofauna did not affect soil quality but increased crop yields in a subhumid tropical maize-based system. Agric Ecosyst Environ 208:75-85. https://doi.org/10.1016/j.agee.2015.04.001

Phiri E, Verplancke H, Kwesiga F, Mafongoya P (2003) Water balance and maize yield following improved sesbania fallow in eastern Zambia. Agrofor Syst 59:197-205

Prates MO, Dey DK, Willig MR et al (2011) Intervention analysis of hurricane effects on snail abundance in a tropical forest using long -term spatiotemporal data. J Agric Biol Environ Statist 16:142-156

R Development Core Team (2020) R: A language and environment for statistical computing. R Foundation for Statistical Computing, Vienna

Ramesh T, Manjaiah KM, Tomar JMS, Ngachan SV (2013) Effect of multipurpose tree species on soil fertility and CO2 efflux under hilly ecosystems of Northeast India. Agrofor Syst 87:1377-1388

Rao MR, Nair PKR, Ong K (1998) Biophysical interactions in tropical agroforestry systems. Agrofor Syst 38:3-49

Ren ZP, Zhang GH, Wang B, Shi YY (2012) Effects of doublering diameter on soil infiltration rate. J Soil Water Conserv 26:94-103

Rosegrant MR, Ringler C, Sulser TB, Ewing M, Palazzo A, Zhu T, Nelson GC, Koo J, Robertson R, Msangi S, Batka M (2009) Agriculture and food security under global change: prospects for 2025/2050. Background note for supporting the development of CGIAR Strategy and Results Framework. International Food Policy Res. Institute: Washington, DC

Rousseau L, Fonte SJ, Téllez O, Van der Hoek R, Lavelle P (2013) Soil macrofauna as indicators of soil quality and land use impacts in smallholder agroecosystems of western Nicaragua. Ecol Indic 27:71-82

Saha R, Ghosh PK, Mishra VK, Majumdar B, Tomar JMS (2010) Can agroforestry be a resource conservation tool to maintain soil health in the fragile ecosystem of north-east India? Outlooks Agric 39(3):191-196

Sanchez PA (1999) Improved fallows come of age in the tropics. Agrofor Syst 47:3-12

Sanchez PA (2002) Soil fertlity and hunger in Africa. Science 295(5562):2019-2020

Sarvade S, Mishra HS, Kaushal R, Chaturvedi S, Tewari S (2014) Wheat (Triticum aestivum L.) yield and soil properties as influenced by different agri-silviculture systems of Terai Region Northern India. Int J Stress Manage 5(3):350-355

Shannon CE, Wiener W (1963) The mathematical theory of communication. University Illinois Press, Urbana

Sheoran V, Sheoran AS, Poonia P (2010) Soil reclamation of abandoned mine land by revegetation: a review. Int J Soil Sediment Water 3(2):1-21

Sileshi G, Mafongoya PL (2006) Long-term effects of improved legume fallows on soil invertebrate macrofauna and maize yield in eastern Zambia. Agric Ecosyst Environ 115:69-78

Sileshi G, Akinnifesi FK, Ajayi OC, Place F (2008a) Metaanalysis of maize yield response to woody and herbaceous legumes in sub-Saharan Africa. Plant Soil 307:1-19

Sileshi G, Chintu R, Mafongoya PL, Akinnifesi FK (2008b) Mixed-species legume fallows affect faunal abundance and richness and $\mathrm{N}$ cycling compared to single species in maize-fallow rotations. Soil Biol Biochem 40:3065-3075

Sileshi GW, Akinnifesi FK, Ajayi OC, Muys B (2011) Integration of legume trees in maize-based cropping systems improves rain use efficiency and yield stability under rainfed agriculture. Agric Water Manag 98:1364-1372

Sileshi GW, Mafongoya PL, Akinnifesi FK, Phiri E, Chirwa P, Beedy T, Makumba W, Nyamadzawo G, Njoloma J, Wuta M, Nyamugafata P, Jiri O (2014) Agroforestry: Fertilizer Trees. In: Neal Van Alfen, editor-in-chief. Encyclopedia of Agriculture and Food Systems, San Diego: Elsevier 1: 222-234.

Silva MCC, Andreotti M, Costa NR, Lima CGR, Pariz CM (2017) Soil physical attributes and yields of winter common bean crop under a no-till system in the Brazilian Cerrado. Rev Caatinga 30:155-163

Somasundaram J, Singh RK, Ali S, Sethy BK, Singh D, Lakaria BL, Chaudhary RS, Singh RK, Sinha NK (2012) Soil aggregates and other properties as influenced by different long-term land uses under table landscape topography of Chambal region Rajasthan, India. J Soil Water Conserv 40(3):212-217

Susilo FX, Nuetal AM, Noordwijk M, Hairiah K, Brown G, Swift MJ (2004) Soil biodiversity and food webs, belowground interactions in tropical agro ecosystems. CAB International, Wallingford

Swift MJ, Shepherd KD (eds) (2007) Saving Africa's soils: science and technology for improved soil management in Africa. World Agroforestry Centre, Nairobi

Tian ML, Tan GX, Liu YJ, Rong TZ, Huang YB (2009) Origin and evolution of Chinese waxy maize: evidence from the Globulin-1 gene. Genet Resour Crop Evolut 56:247-255 
Tittonell P (2016) Feeding the world with soil science: embracing sustainability, complexity and uncertainty. SOIL Discuss. https://doi.org/10.5194/soil-2016-7

Tittonell P, Giller K (2013) When yield gaps are poverty traps: the paradigm of ecological intensification in African smallholder agriculture. Field Crops Res 143:76-90

Urbanovicova V, Miklisov D, Mock A, Kov L (2014) Activity of epigeic arthropods in differently managed windthrown forest stands in the High Tatra Mts. North-Western J Zool 10:337-345

Wick AF, Ingram LJ, Stahl PD (2009) Aggregate and organic matter dynamics in reclaimed soils as indicated by stable carbon isotopes. Soil Biol Biochem 41:201-209

Yang ZP, Xu MG, Zheng SX, Jun NI, Gao JS, Liao YL, Jian X (2012) Effects of long-term winter planted green manure on physical properties of reddish paddy soil under a doublerice cropping system. J Integr Agric 11:655-664
Yoder RE (1936) A direct method of aggregate analysis of soils and a study of the physical nature of erosion losses. JASA 28:337-351

Yun L, Bi H, Gao L, Zhu Q, Ma W, Cui Z, Wilcox BP (2012) Soil moisture and soil nutrient content in walnut-crop intercropping in the Loess Plateau of China. Arid Land Res Manage 26:285-296

Zingore S, Mutegi J, Agesa B, Tamene L, Kihara J (2015) Soil degradation in sub-Saharan Africa and crop production options for soil rehabilitation. Better Crops 99:24-26

Publisher's Note Springer Nature remains neutral with regard to jurisdictional claims in published maps and institutional affiliations. 